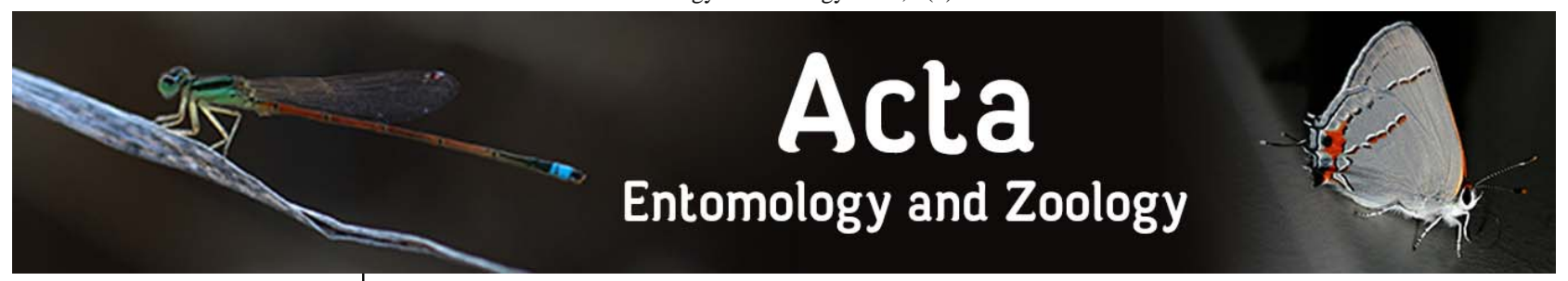

E-ISSN: 2708-0021 P-ISSN: 2708-0013 www.actajournal.com AEZ 2020; 1(2): 10-16 Received: 05-05-2020 Accepted: 09-06-2020

Moustafa MS Bakry Scale Insects and Mealybugs Research Department, Plant Protection Research Institute, A.R.C, Dokii, Giza, Egypt

Lamiaa HY Mohamed Scale Insects and Mealybugs Research Department, Plant Protection Research Institute, A.R.C, Dokii, Giza, Egypt

Shimaa YE Shakal Plant Prot. Department, Fac. of Agric. and Natural Resources, Aswan Univ. Aswan, Egypt
Corresponding Author: Moustafa MS Bakry Scale Insects and Mealybugs Research Department, Plant Protection Research Institute, A.R.C, Dokii, Giza, Egypt E-mail: md.md_sabry@yahoo.com

\section{Host preference of certain mango varieties to infestation with the mango shield scale, Milviscutulus mangiferae (Green) (Hemiptera: Coccidae) in Ismailia governorate, Egypt}

\author{
Moustafa MS Bakry, Lamiaa HY Mohamed and Shimaa YE Shakal
}

DOI: https://doi.org/10.33545/27080013.2020.v1.i2a.12

\begin{abstract}
A field study was carried out at a private mango orchard at Abu-Suwair district in Ismailia Governorate, Egypt during two successive years from (January 2018 to December 2019) to study the performance of some mango varieties to infestation with the mango shield scale, Milviscutulus mangiferae (Green) (Hemiptera: Coccidae). The obtained results showed that insect population of $M$. mangiferae occurred on all different mango varieties all the year round and has three peaks of seasonal activity per year, which was recorded in January, June/July and November over the year. The obtained results indicated that the mango varieties varied significantly in their susceptibility to population density of $M$. mangiferae. Ewaise mango variety was the highest population density and was rated as highly susceptible (H.S.) to infestation by the total population density of M. mangiferae, followed by Zebda and Fagri Kalan mango varieties were appeared as susceptible (S), while, Balady variety was observed to be relatively resistant (RR). But, Sakary variety had the lowest population density and was rated as relative resistant (RR) of pest over the entire year. These pieces of information can be useful for establishing IPM strategies against this pest.
\end{abstract}

Keywords: Milviscutulus mangiferae, population density, host preference, mango varieties

\section{Introduction}

Mango trees, Mangifera indica L. (Anacardiaceae) are considered of the most popular fruit in Egypt. Egyptian mangoes occupy economic importance in the world market for rich flavor and taste. Among several pests, infesting mango trees, the mango shield scale, Milviscutulus mangiferae (Green) (Hemiptera: Coccidae) is considered one of the most main destructive pests of mango trees (Abd-Rabou and Evans, 2018; Attia et al., 2018 and El-Baradey et al., 2020) $)^{[1,3,8]}$.

This pest injures the shoots, twigs, leaves, branches and fruits by sucking the plant sap with the mouth parts, causing thereafter deformations, defoliation, drying up of young twigs, dieback, poor blossoming, death of twig by the action of the toxic saliva (Soliman et al., 2007; Hassan et al., 2012 and Bakry et al., 2013) ${ }^{[27,13,5] .}$

In addition, this pest excrete a large amount of honeydew that cover plant leaves and attract ants on leaves and encourages the growth of sooty mould fungus which gives infested dirty black appearance that affect on photosynthesis and respiration and otherwise reduces the quality of the plant causing considerable economic injury (Atalla et al., 2007 and Nabil, $2013)^{[2,20]}$. Heavy infestation of $M$. mangiferae results in reduced tree vigour and leaf size, causing yellowing of the leaves, leaf drop and death of the branches (Grimshaw and Donaldson, 2007) ${ }^{[12]}$.

Plant resistance to insect pests is one of the most important components of the integrated pest management (IPM). A wide array of chemical substances including inorganic chemicals, primary and intermediary metabolites and secondary substances are known to impart resistance to a wide cultivar of insect pests. The host plant may also be deficient in certain nutritional elements required by the insects and hence prove resistant (Dhaliwal and Singh, 2004) ${ }^{[7]}$.

The host plant may also be deficient in certain nutritional elements required by the insects and hence appear to be resistant (Karar et al., 2015) ${ }^{[16]}$. There are many factors, which have affected on the feeding attraction of the scale, one of these factors inside plant itself which 
makes the plant resistant or susceptible may be genetic factors, or phenotypic due to differences in environmental factors such as the nutritional status of the soil (Dale, 1988) ${ }^{[6]}$ or air pollution (Riemer and Whittaker, 1989) ${ }^{[23]}$, or variation in plant age or seasonal phenology (Marino and Cornell, 1993) ${ }^{[18]}$. A resistant variety may be less preferred by the insect pest, adversely affect its normal development and survival or the plant may tolerate the damage without an economic loss in yield or quality (Hoffmann and Frodsham, 1993) ${ }^{[15]}$.

Having information about density and changes in population of $M$. mangiferae during the year, identification of factors affecting population fluctuations and determination of their effects will help mango producers in management of this pest. Little information is available in the literature concerning the effect of the host preference on the infestation level by $M$. mangiferae. Therefore, the present work was carried out to evaluate the susceptibility of five varieties of mango to infestation by $M$. mangiferae at AbuSuwair district in Ismailia Governorate, Egypt, by considering general mean number of insect population or infestation by $M$. mangiferae per variety, as the standard of classification.

\section{Materials and methods \\ Study area}

The present study was carried out in private mango orchard, Mangifera indica L., of approximately ten feddans, of 8 years-old was selected at Abu Suwair district in Ismailia Governorate. The different mango varieties were Ewaise, Fagri Kalan, Balady, Zebda and Sakary, and was sampled twice monthly from the beginning of January, 2018 until mid of December, 2019.

Five mango trees from each variety, of almost uniform and of similar in size, height, vegetative growth and receiving the same horticultural practices (i.e. irrigation, fertilization, and pruning), were selected and labeled. These randomly chosen mango trees did not receive any pesticidal control measures before and during the period of investigation. Regular bimonthly samples of 40 leaves per tree were randomly picked representing the four directions and three levels (heights) of each tree. Leaf samples were randomly picked from the terminal shoots of tree. Every sample was placed in a polyethylene bag and all samples of every date were transferred to the laboratory for inspection using a stereo-microscope.

Numbers of live insects on upper and lower surfaces of mango tree leaves were individually sorted into immature stages (nymphs) and mature stages (adult females) and then were counted and recorded, linked to the inspection date, and presented as mean number of individuals per leaf \pm standard error (SE), to express the population size of pest, but, the data were discussed through monthly records.

\section{General sampling method}

All sampling was conducted from 48000 leaves on 48 dates over a 2-year period, i.e. 5 trees $\times 40$ leaves $\times 5$ varieties $\times$ 48 dates. The data obtained were statistically analyzed by using the analysis of variance. The means were compared according to Least Significant Difference test (LSD) at the $5 \%$ level to determine the significance among means of varieties, by computer (MSTATC Program software, 1980) ${ }^{[19]}$. Averages of different stages of insect population were calculated and shown graphically by Excel sheets.
- Coefficient of variance (C.V.): To assess the fidelity of sampling and the comparison between different mango varieties:

$C . V .=(S / \bar{X}) \times 100$

where, $S$ is the standard deviation of the mean and $\bar{X}$ is the mean of the population.

- Relative Variation (R.V.) is employed to compare the efficiency of various sampling methods among different mango varieties (Hillhouse and Pitre 1974) ${ }^{[14]}$. The relative variation for the studied seasons was calculated as follows:

$R . V .=(S E / \bar{X}) \times 100$

Where, $S E$ is the standard error of the mean and $\bar{X}$ is the mean of the population.

\section{Susceptibility degrees}

Classification of the tested mango varieties to their susceptibility degrees was adopted as described by (Semeada, 1985 and Nosser, 1996) ${ }^{[26,22]}$ based on a quantitative approach found to the following assumptions:

A. Varieties were grouped into five categories: i.e. resistant (R), moderate resistant (MR), relative resistant (RR), susceptible (S), and highly susceptible (HS).

\section{B. General mean number of individuals $=(\mathrm{MN})$}

C. Range of change (RC): between the maximum mean number values and minimum for the varieties was calculated by applying the following equation:

\section{$\mathrm{RC}=\mathrm{MN} \max -\mathrm{MN} \min$}

where,

MN max = maximum number of individuals/ varieties .

MN min= minimum number of individuals/ varieties.

D. Unit change in varieties (UC) was the amount of change in varieties from one degree of resistance or susceptibility to the preceding degree (from MR to $\mathrm{R}$ or from MR to RR ...etc).

According to the above mentioned equation, the tested varieties could be classified as the follows:

1. The highly susceptible group (HS): varieties with infestation more than (MN+ UC).

2. The susceptible group (S): varieties with infestation ranging from $\mathrm{MN}$ to (MN+UC).

3. The relative resistant group (RR): varieties with infestation less than MN to (MN-UC).

4. The moderate resistant group (MR): varieties with infestation ranging from < (MN-UC) to (MN-2UC).

5. The resistant group (R): verities with infestation less than (MN- 2UC).

However, it is an important to point out herein that the pest mean numbers must refer to and / or agree with the resistance degree of variety.

\section{Results and discussion}

1. Seasonal abundance of $M$. mangiferae on certain mango varieties

The monthly counts of $M$. mangiferae different stages on certain mango varieties at Abu-Suwair district, Ismailia 
Governorate were recorded through the two successive years from (beginning of January, 2018 to mid of December 2019) are represented in Figs. (1 and 2). But, the data were discussed through monthly records.

The obtained results are illustrated in Figs. (1 and 2), showed that the nymphs, adult females and total insect population by $M$. mangiferae occurred on all tested mango varieties all the year round and has three peaks of seasonal activity per year, which was recorded in January, June/July and November over the year.

These results were coincided with those obtained by ElDash (1997) ${ }^{[9]}$ in Shebin El-Kom, Egypt, recorded that $K$. acuminata (Sign.) had two generations annually in mango trees. Also, Kwaiz (1999) ${ }^{[17]}$ in Qalubyia, Egypt, reported that $K$. acuminata had two generations, the first generation extended from early September to early May, and the second generation started from early March to early September. Elwan (2007) ${ }^{[11]}$ in Qalubyia Governorate, Egypt, indicated that $K$. acuminata had two annual overlapping generations per year. The first generation occurred during January and the second generation extended from the late of July to the half of February. Bakry et al.

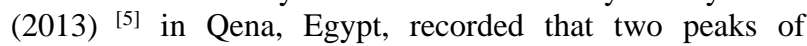
seasonal activity per year. But, Atalla et al. (2007) ${ }^{[2]}$ in Qalubyia, Egypt, indicated that K. acuminata had three annual overlapping generations per year. The peaks occurred in the first of January, mid-October and mid of December. El-Dash et al. (2002) ${ }^{[10]}$ who revealed that the total average of total monthly count indicated three peaks of abundance in May, July and October- November. Hassan et al. (2012) ${ }^{[13]}$ in Sharkia Governorate, Egypt, reported that the total alive stages of $K$. acuminata had two to three peaks of activity yearly in both top and bottom levels of the trees. Attia et al. (2018) [3] in Qalubyia Governorate, Egypt, indicated the occurrence of three generations per year for $M$. mangiferae on mango trees.

Results as represented in Figs. (1 and 2), showed that the nymphs population was relatively higher than the adult females population in all tested mango varieties during the two successive years. Also, the least population density of different stages and total population of $M$. mangiferae were recorded during February in all different mango varieties during the two years of study, which may be attributed to the high relative humidity with the gradual decrease in temperature and dormancy of the trees during winter season which is expected to effect dramatically the insect behaviour and on rate of growth and infestation. In contrary, the maximum values of insect population in November month during the two years in all tested mango varieties. When crawlers emerged after the egg laying period, their population decreased during several months due to mortality of nymphs stage in the winter. It appeared that, the annual fluctuations in the population density during the two years were affected by the variability in these physical factors in the both years of investigation. These results were coincided with those obtained by El-Baradey et al. (2020) ${ }^{[8]}$.

\section{Susceptibility of certain mango varieties to infestation by $M$. mangiferae \\ A. Nymphs population}

Data represented in Table (1), showed that the mean population density of $M$. mangiferae nymphs per leaf from each of the five mango varieties. It is clear that, Ewaise mango variety occupied the highest number of $M$. mangiferae nymphs with an average of $31.46 \pm 2.90,28.60$ \pm 2.77 and $30.03 \pm 2.81$ individuals per leaf over the first, second years, and on the average years data, respectively as compared to the other tested varieties and was appeared as highly susceptible (HS). However, the lowest number was recorded on Sakary variety with an average of $9.00 \pm 0.83$, $6.72 \pm 0.61$ and $7.86 \pm 0.71$ individuals per leaf and was seemed as relative resistant (RR) through the first and second years, and on the average years data, respectively. While, Zebda and Fagri Kalan varieties were observed as susceptible (S) during the first and second years, and on the average years, with an average of $22.72 \pm 2.13,17.44 \pm 1.66$ and $20.08 \pm 1.88$ individuals per leaf for Zebda variety and was $19.92 \pm 1.83$, $16.88 \pm 1.59$ and $18.40 \pm 1.70$ individuals per leaf for Fagri Kalan variety, respectively. On the other hand, Balady variety was rated as relatively resistant (RR) with an average of $10.48 \pm 0.96,7.89 \pm 0.76$ and $9.19 \pm 0.86$ individuals per leaf during the first, second years, and on the average years, respectively.

Statistically, highly significant differences among the five tested mango varieties regarding the level of infestation by M. mangiferae nymphs were obtained (L.S.D. values were 1.18, 1.17 and 1.17) through the first, second years and average the two years, respectively. As well, highly significant differences between the first and the second years for $M$. mangiferae (L.S.D. value was 0.97 ), the mean numbers of nymphs were higher in the first year (18.71 \pm 1.00 per leaf) as compared the second year (15.51 \pm 0.90 per leaf).

The coefficient of variance among different mango varieties were recorded (15.68, 18.67 and 16.92\%) through the first and second years, and on the average years, respectively. As well, the obtained values in Table (1) showed that the relative variation (R.V.\%) for the sampling data of $M$. mangiferae on different mango varieties indicated that the population densities of $M$. mangiferae nymphs were 5.32, 5.80 and $5.50 \%$ in the all different mango varieties through the first and second years, and on the average years data, respectively. The values of R.V.\% were very appropriate for a sampling program to compare the among different mango varieties. However, with different insect species and different host, Naeimamini et al. (2014) ${ }^{[21]}$ stated that the relative variation for the primary sampling data of different stages of Pulvinaria floccifera (Hemiptera: Coccidae) were less than $25 \%$ and were acceptable.

\section{B. Adult females' population}

The data in Table (2), shows the population density of $M$. mangiferae adult females' per leaf from each of the five mango varieties. Out of the five varieties of mango, Sakary variety was found as relatively resistant (RR) and occupied the smallest population with an average of $9.93 \pm 0.35,6.16$ \pm 0.29 and $8.04 \pm 0.30$ individuals per leaf over the first and second years, and on the average years, respectively as compared to the other tested varieties. On contrary, Ewaise mango variety was appeared as highly susceptible (HS) with an average of $17.36 \pm 0.61,15.39 \pm 0.73$ and $16.37 \pm 0.63$ individuals per leaf through the first and second years, and on the pooled data, respectively. Meanwhile, Zebda and Fagri Kalan varieties were moderately population of pest during the first and second years, and on the average years data, with an average $15.03 \pm 0.53,12.00 \pm 0.57$ and 13.52 \pm 0.52 individuals per Zebda mango leaf and was $14.46 \pm$ $0.51,12.82 \pm 0.61$ and $13.64 \pm 0.52$ individuals per Fagri 
Kalan mango leaf, respectively. These varieties were seemed as susceptible (S) during the two years, respectively. But, Balady variety was appeared as relatively resistant (RR) with an average of $10.36 \pm 0.36,9.19 \pm 0.43$ and 9.78 \pm 0.38 individuals per leaf during the first and second years, and on the average years data, respectively.

Statistical analysis of data resulted highly significant differences among the five tested varieties regarding the level of infestation by $M$. mangiferae adult females were obtained (L.S.D. values were 2.10, 2.85 and 2.35) through the first and second years, and on the average years data, respectively. It is clear from the results that, highly significant differences between the first and the second years for $M$. mangiferae adult females' population (L.S.D. was 0.18 ). The mean numbers of adult females were smaller in the second year (11.11 \pm 0.32 per leaf) as compared the first year (13.43 \pm 0.28 per leaf).

Also, coefficient of variance between different mango varieties were recorded (3.05, 5.11 and 3.77\%) through the first and second years, and on the average years, respectively. It is clear from the results that, the relative variation (R.V.\%) for the sampling data of M. mangiferae on different mango varieties indicated that the population densities of $M$. mangiferae adult females were 2.10, 2.85 and $2.35 \%$ in the all different mango varieties through the first and second years, and on the average years data, respectively.

\section{Total population of $M$. mangiferae (nymphs + adult females)}

Data represented in Table (3), revealed that there was a highly significant difference among mango varieties to infestation by $M$. mangiferae total mixed population (L.S.D. values were 1.32, 1.34 and 1.32) through the first and second years, and on the average years data, respectively. The maximum number of total population of pest was observed on Ewaise variety with an average of $48.81 \pm 3.45$, $43.99 \pm 3.39$ and $46.40 \pm 3.38$ individuals per leaf during the first and second years, and on the average years, respectively as compared to the other tested varieties and was appeared as highly susceptible (HS). However, the minimum individuals of total population of $M$. mangiferae was recorded on Sakary variety with an average of $18.92 \pm$ $1.15,12.88 \pm 0.87$ and $15.90 \pm 0.99$ individuals per leaf through the first and second years, and on the average years data, respectively and was rated as relatively resistant (RR). On the other hand, Zebda and Fagri Kalan varieties were observed as susceptible (S) during the first and second years, and on the average years, with an average of $37.75 \pm$ 2.62, $29.44 \pm 2.15$ and $33.60 \pm 2.34$ individuals per leaf for Zebda variety and was $34.38 \pm 2.30,29.71 \pm 2.12$ and 32.05 \pm 2.18 individuals per leaf for Fagri Kalan variety, respectively. But, Balady variety was rated as relatively resistant (RR) with an average of $20.84 \pm 1.30,17.08 \pm 1.15$ and $18.96 \pm 1.20$ individuals per leaf during the first and second years, and on the average years data, respectively. It is clear from the results that, the general averages of total live $M$. mangiferae individuals were higher during the first year was (32.14 \pm 1.26 per leaf) in comparison to the second year of study (26.62 \pm 1.18 per leaf). As well, highly significant differences between the first and the second years for M. mangiferae total population (L.S.D. was 1.11).
It is clear from the results that, the coefficient of variance among different mango varieties were recorded (10.22, 12.45 and $11.14 \%$ ) through the first and second years, and on the average years, respectively. As well, the relative variation (R.V.\%) for the sampling data of $M$. mangiferae on different mango varieties indicated that the population densities of $M$. mangiferae total population were 3.91, 4.43 and $4.10 \%$ in the all different mango varieties through the first and second years, and on the average years data, respectively.

It is obvious that the differences in the values of population densities of $M$. mangiferae on certain mango varieties which may be due to the differences not only in the environmental conditions (such as temperature, relative humidity) but also there are numerous other factors such as the leaf structure (density of stomata, softness of tissues and size of leaves) as well as growth features (such as growing period) for the tested varieties of mango.

In general, it could be concluded that Ewaise mango variety was the most preference for population density with the mango shield scale, $M$. mangiferae, followed by Zebda, then by Fagri Kalan and Balady, while the Sakary variety was less preferable variety for this insect. The tested varieties could be arranged according to their susceptibility in a descending order as follows:

Ewaise $>$ Zebda $>$ Fagri Kalan $>$ Balady $>$ Sakary.

We concluded that the host plant affects the development of pest and that the choice of the most appropriate variety can help to reduce pest infestation, and is therefore an additional component to be included in the integrated pest management of mango. The degree of infestation on different mango varieties varied according to insect species. In this respect, Salem (1994) ${ }^{[24]}$ in Egypt, however with different insect species, also studied the susceptibility of five mango varieties to infestation with three species of scale, Insulaspis pallidula (Green) (Hemiptera: Diaspididae), Kilifia acuminata (Signoret) (Homoptera: Coccidae) and Parlatoria oleae (Colvee) (Homoptera: Diaspididae), he reported that Zebda and Hindy vareities were highly susceptible to infestation with the previously scale insects; Dabsha cultivar was moderately susceptible, while Timour and Alphonso cultivars were highly resistant. He suggested that the differences in susceptibility could be attributed to the morphological characters of the leaves of these cultivars. Selim (2002) ${ }^{[25]}$ in Egypt, however with different insect species, also studied the susceptibility of five mango varieties to infestation with two armoured scale insect pest, $I$. pallidula and A. aurantii and recorded that $I$. pallidula infested all varieties more than $A$. aurantii. On the other hand, the variety Hindy was the most susceptible variety to infestation with both scale insects followed by Mabrouka, then by Kobania and Taimour, while the least susceptible variety was Dabsha. Bakry (2009) ${ }^{[4]}$ in Egypt, however with different insect species, also studied the variability among four mango varieties in the levels of infestation with two armoured scale insects, I. pallidula and A. aurantii. He recorded that the population density of $A$. aurantii was greater than that of I. pallidula. On the other hand, grafted Balady was the most infested variety with the two scale insects followed by Hindy, then by Goleck, while the least infested variety was seedy Balady variety for two scale insects. 
Table 1: Mean numbers of M. mangiferae nymphs population on different mango varieties during the years of 2018 and 2019.

\begin{tabular}{|c|c|c|c|c|}
\hline \multirow{2}{*}{ Mango varieties } & \multicolumn{3}{|c|}{$\begin{array}{l}\text { Average no. of nymphs individuals of insect per } \\
\text { leaf } \pm \text { S.E }\end{array}$} & \multirow{2}{*}{$\begin{array}{c}\text { Susceptibility } \\
\text { degree }\end{array}$} \\
\hline & $\begin{array}{l}\text { First year } \\
(2018)\end{array}$ & $\begin{array}{l}\text { Second year } \\
(2019)\end{array}$ & $\begin{array}{l}\text { Average of } \\
\text { both years }\end{array}$ & \\
\hline Ewaise & $31.46 \pm 2.90 \mathrm{a}$ & $28.60 \pm 2.77 a$ & $30.03 \pm 2.81$ a & HS \\
\hline Fagri Kalan & $19.92 \pm 1.83 \mathrm{~b}$ & $16.88 \pm 1.59 \mathrm{~b}$ & $18.40 \pm 1.70 \mathrm{~b}$ & $\mathrm{~S}$ \\
\hline Balady & $10.48 \pm 0.96 \mathrm{c}$ & $7.89 \pm 0.76 \mathrm{c}$ & $9.19 \pm 0.86 \mathrm{c}$ & RR \\
\hline Zebda & $22.72 \pm 2.13 b$ & $17.44 \pm 1.66 \mathrm{~b}$ & $20.08 \pm 1.88 b$ & $\mathbf{S}$ \\
\hline Sakary & $9.00 \pm 0.83 \mathrm{c}$ & $6.72 \pm 0.61 \mathrm{c}$ & $7.86 \pm 0.71 \mathrm{c}$ & $\mathbf{R R}$ \\
\hline General mean & $18.71 \pm 1.00 \mathrm{a}$ & $15.51 \pm 0.90 \mathrm{~b}$ & $17.11 \pm 0.94$ & \\
\hline C.V.\% & 15.68 & 18.67 & 16.92 & \\
\hline R.V.\% & 5.32 & 5.80 & 5.50 & \\
\hline $\begin{array}{l}\text { L.S.D. at } 0.05 \\
\text { between varieties }\end{array}$ & 1.18 ** & 1.17 *w & $1.17^{* *}$ & \\
\hline $\begin{array}{c}\text { L.S.D. at } 0.05 \\
\text { between two years }\end{array}$ & \multicolumn{2}{|c|}{0.97 « } & & \\
\hline
\end{tabular}

Table 2: Mean numbers of M. mangiferae adult females population on different mango varieties during the two successive years of 2018 and 2019.

\begin{tabular}{|c|c|c|c|c|}
\hline \multirow{2}{*}{ Mango varictics } & \multicolumn{3}{|c|}{$\begin{array}{l}\text { Average no. of adult females individuals of } \\
\text { insect per leaf } \pm \text { S.E }\end{array}$} & \multirow{2}{*}{$\begin{array}{c}\text { Susceptibility } \\
\text { degree }\end{array}$} \\
\hline & $\begin{array}{l}\text { First year } \\
(2018)\end{array}$ & $\begin{array}{l}\text { Second year } \\
\text { (2019) }\end{array}$ & $\begin{array}{l}\text { Average of } \\
\text { both years }\end{array}$ & \\
\hline Ewaise & $17.36 \pm 0.61$ a & $15.39 \pm 0.73$ a & $16.37 \pm 0.63 \mathrm{a}$ & HS \\
\hline Fagri Kalan & $14.46 \pm 0.51 \mathrm{~b}$ & $12.82 \pm 0.61 \mathrm{~b}$ & $13.64 \pm 0.52 \mathrm{~b}$ & $\mathrm{~S}$ \\
\hline Balady & $10.36 \pm 0.36 \mathrm{c}$ & $9.19 \pm 0.43 \mathrm{c}$ & $9.78 \pm 0.38 \mathrm{c}$ & RR \\
\hline Zebda & $15.03 \pm 0.53 \mathrm{~b}$ & $12.00 \pm 0.57 \mathrm{~b}$ & $13.52 \pm 0.52 \mathrm{~b}$ & $\mathrm{~S}$ \\
\hline Sakary & $9.93 \pm 0.35 c$ & $6.16 \pm 0.29 \mathrm{c}$ & $8.04 \pm 0.30 c$ & RR \\
\hline General mean & $13.43 \pm 0.28$ a & $11.11+0.32 \mathrm{~b}$ & $12.27+0.29$ & \\
\hline C.V.\% & 3.05 & 5.11 & 3.77 & \\
\hline R.V.\% & 2.10 & 2.85 & 2.35 & \\
\hline $\begin{array}{c}\text { L.S.D. at } 0.05 \\
\text { between varieties }\end{array}$ & $2.10 * \%$ & $2.85 * \%$ & $2.35 * *$ & \\
\hline $\begin{array}{l}\text { L.S.D. at } 0.05 \\
\text { between two years }\end{array}$ & \multicolumn{2}{|c|}{0.18 ** } & & \\
\hline
\end{tabular}

Table 3: Mean numbers of M. mangiferae total population on different mango varieties during the two successive years of 2018 and 2019.

\begin{tabular}{|c|c|c|c|c|}
\hline \multirow{2}{*}{ Mango varieties } & \multicolumn{3}{|c|}{$\begin{array}{l}\text { Average no. of total population of insect per leaf } \pm \\
\text { S.E }\end{array}$} & \multirow{2}{*}{$\begin{array}{l}\text { Susceptibility } \\
\text { degree }\end{array}$} \\
\hline & $\begin{array}{l}\text { First year } \\
(2018)\end{array}$ & $\begin{array}{l}\text { Second year } \\
(2019)\end{array}$ & $\begin{array}{l}\text { Average of } \\
\text { both years }\end{array}$ & \\
\hline Ewaise & $48.81 \pm 3.45 \mathrm{a}$ & $43.99 \pm 3.39 \mathrm{a}$ & $46.40 \pm 3.38 \mathrm{a}$ & HS \\
\hline Fagri Kalan & $34.38 \pm 2.30 \mathrm{~b}$ & $29.71 \pm 2.12 b$ & $32.05 \pm 2.18 \mathrm{~b}$ & $\mathbf{S}$ \\
\hline Balady & $20.84 \pm 1.30 \mathrm{c}$ & $17.08 \pm 1.15 \mathrm{c}$ & $18.96 \pm 1.20 \mathrm{c}$ & $\mathbf{R R}$ \\
\hline Zebda & $37.75 \pm 2.62 \mathrm{~b}$ & $29.44 \pm 2.15 \mathrm{~b}$ & $33.60 \pm 2.34 \mathrm{~b}$ & $\mathbf{S}$ \\
\hline Sakary & $18.92 \pm 1.15 \mathrm{c}$ & $12.88 \pm 0.87 \mathrm{c}$ & $15.90 \pm 0.99 \mathrm{c}$ & $\mathbf{R R}$ \\
\hline General mean & $32.14 \pm 1.26 \mathrm{a}$ & $26.62 \pm 1.18 \mathrm{~b}$ & $29.38 \pm 1.21$ & \\
\hline C.V.\% & 10.22 & 12.45 & 11.14 & \\
\hline R.V.\% & 3.91 & 4.43 & 4.10 & \\
\hline $\begin{array}{c}\text { L.S.D. at } 0.05 \\
\text { between varieties }\end{array}$ & $1.32 * *$ & $1.34 * *$ & $1.32 * *$ & \\
\hline $\begin{array}{l}\text { L.S.D. at } 0.05 \\
\text { between two years }\end{array}$ & \multicolumn{2}{|c|}{$1.11 * *$} & & \\
\hline
\end{tabular}




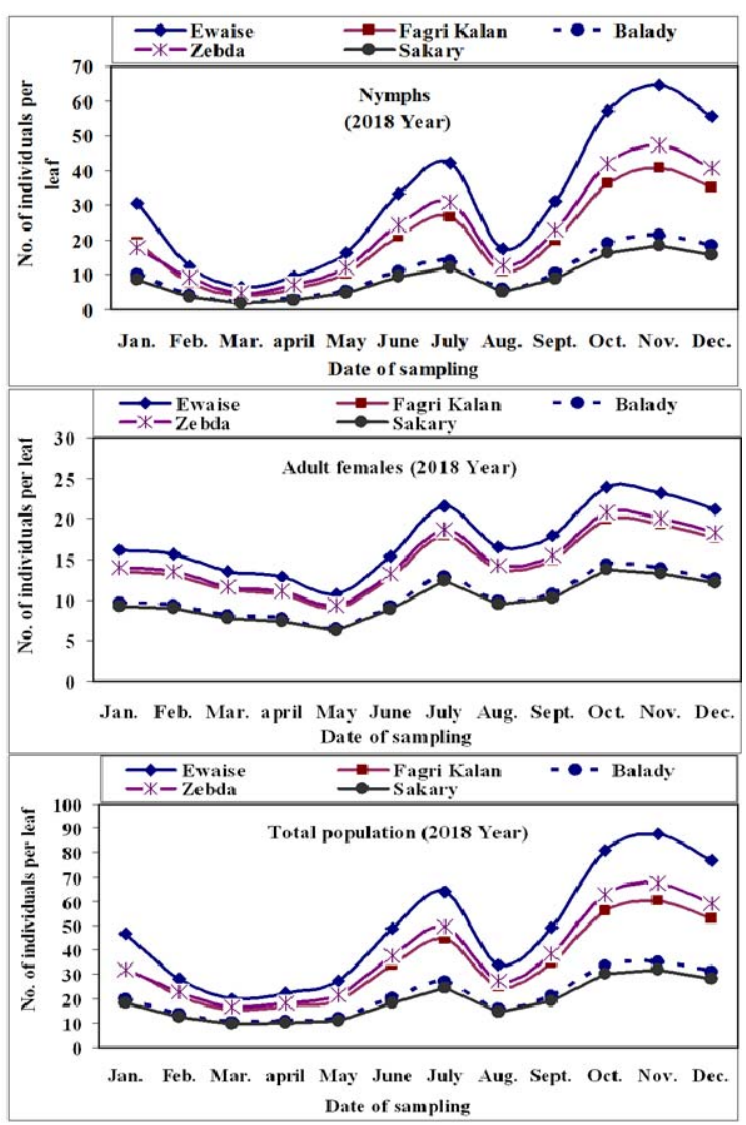

Fig 1: Seasonal abundance of different stages of M. mangiferae on certain mango varieties during 2018 year.

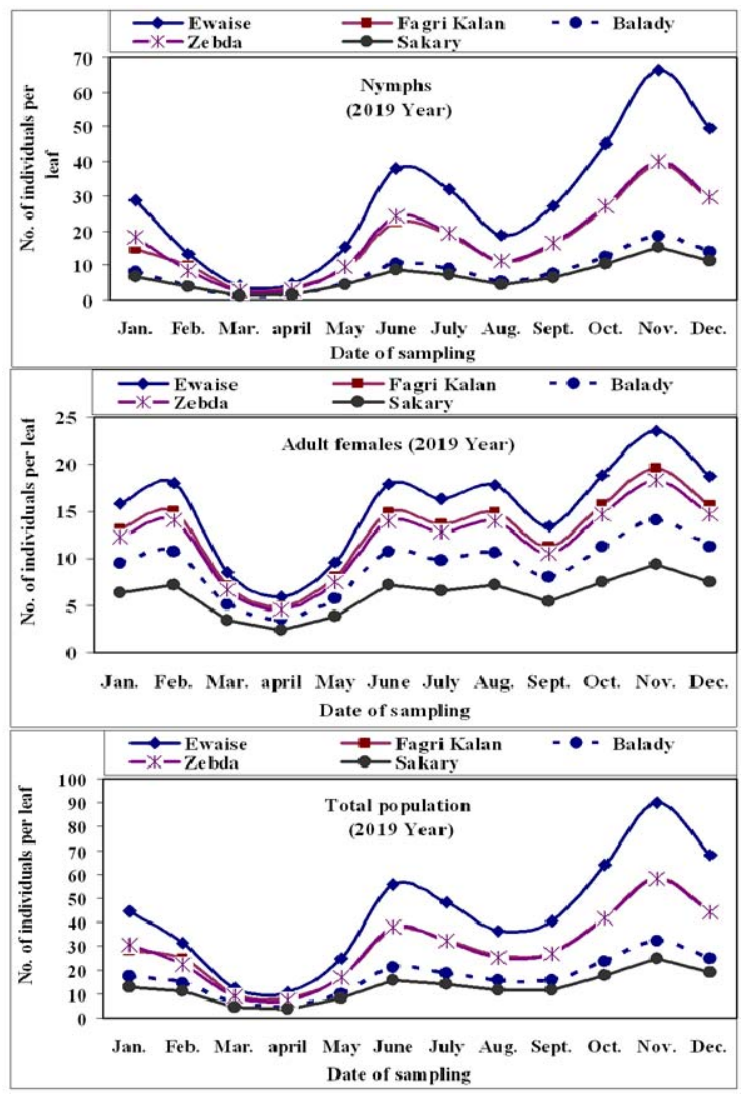

Fig 2: Seasonal abundance of different stages of $M$. mangiferae on certain mango varieties during 2019 year.

\section{References}

1. Abd-Rabou S, Evans GA. The Mango Shield scale, Milviscutulus mangiferae (Green) (Hemiptera: Coccidae). A new invasive soft scale in Egypt. Acta Phytopathologica et Entomologica Hungarica. 2018; 53(1):91-96.

2. Atalla FA, Kwaiz FA, Attla AR. Seasonal abundance of the mango soft scale insect, Kilifia acuminate (Signoret) (Hemiptera: Coccidae) and its parasitoids in Qalubyia Governorate, Egypt. Bull. Soc. Ent. Egypt. 2007; 84:103-110.

3. Attia SA, El-Sayid MI, Abd-ELAziz SY. Abundance and generation determination of the mango shield scale, Milviscutulus mangiferae (Green) (Coccidae: Homoptera) an Invasive Coccid Infesting Mango Orchards at Qaliobiya Gevernorate. J Plant Prot. And Path., Mansoura Univ. 2018; 9(3):209-213.

4. Bakry MMS. Studies on some scale insects and mealybugs infesting mango trees in Qena Governorate. M.Sc. Thesis, Fac. Agric. Minia, Univ, 2009, 204.

5. Bakry MMS, Moussa SFM, Mohamed GH, Abd-Rabou S, El-Amir SM. Observations on the population density of the mango soft scale insect, Kilifia acuminate (Hemiptera: Coccidae) infesting mango trees at Armant district, Qena Governorate, Egypt. Egypt. J Agric. Res. 2013; 91(3):113-135.

6. Dale D. Plant-mediated effects of soil mineral stress on insects. In: E.A. Heinrichs (ed), Plant stress-insect interactions. John Wiley \& Sons, New York, U.S.A, 1988, 35-110.

7. Dhaliwal GS, Singh R. Host plant resistance to insects: concepts and applications. New Delhi, Panima Pub, 2004, 578.

8. El-Baradey WMM, Bakry MMS, El-Zoghby IRM. Population dynamics of the mango shield scale, Milviscutulus mangiferae (Green) on mango trees in Kafr El-Sheikh Governorate, Egypt. International Journal of Research in Agriculture and Forestry. 2020; 7(4):15-24.

9. El-Dash AA. Abundance and bionomics of Lecanium acuminatum Signoret (Homoptera: Coccidae). Menufiya J Agric. Res. 1997; 22(1):155-166.

10. El-Dash AA, Kasim YI, El-Komy SO. Influence of chemical components of host plant and weather factors on population density of Lecanium acuminatum Signoret (Homoptera: Coccoidae). Menufiya J. Agric. Res. 2002; 4(1):887-898.

11. Elwan EA. Population fluctuation of Acuminata scale, Kilifia acuminata (Sign.) (Homoptera: Diaspididae) on mango trees in Egypt Arab J Plant Prot. 2007; 52(1):3242.

12. Grimshaw JF, Donaldson JF. New record of mango shield scale, Milviscutulus mangiferae (Green) (Hemiptera: Coccidae) and Brevennia rehi (Lindinger) (Hemiptera: Pseudococcidae) in north Queensland. Austral Entomology. 2007; 46(2):96-98.

13. Hassan AS, Nabil HA, Shahein AA, Hammad KAA. Some ecological aspects of Kilifia acuminate (Hemiptera: Coccidae) and its parasitoids on mango trees at Sharkia Governorate, Egypt. Egypt. Acad. J Biolog. Sci. 2012; 5(3):33-41.

14. Hillhouse TL, Pitre $\mathrm{HN}$ : of sampling techniques to obtain measurements of insect populations on soybeans. J Econ. Entomol. 1974; 67:411-414. 
15. Hoffmann MP, Frodsham AC. Natural enemies of vegetable insect pests. Integrated Pest Management. Cooperative Extension, Cornell Univ., Ithaca, NY, 1993, 63.

16. Karar H, Arif MJ, Arshad M, Ali A, Abbas Q. Resistance/susceptibility of different mango cultivars against mango mealybug (Drosicha mangiferae G.) Pak. J Agri. Sci. 2015; 52(2):365-375.

17. Kwaiz FAM. Ecological and toxicological studies on the mango soft scale, Kilifia acuminata (Signoret) with special reference to insecticide residues in mango fruits. Ph.D. Thesis, Cario, Univ. Egypt, 1999, 171.

18. Marino PC, Cornell HV. Adult feeding and oviposition of Phytomyza ilicicola Loew (Diptera: Agromyzidae) in response to leaf and tree phenology. Environ. Entomol. 1993; 22:1294-1301.

19. MSTATC. A Microcomputer Program of the Design Management and Analysis of Agronomic Research Experiments. Michigan State Univ., USA., 1980.

20. Nabil HA. Relationship between Kilifia acuminata (Signoret) and chlorophyll percentage loss on mango leaves J of Entomology. 2013; 10(2):110-114.

21. Naeimamini S, Abbasipour H, Aghajanzadeh S. Spatial distribution of the cottony camellia scale, Pulvinaria floccifera (Westwood) (Hemiptera: Coccidae) in the tea orchards. J Plant Prot. Res. 2014; 54(1):44-52.

22. Nosser MA. Mechanism of resistance in bean and cowpea varieties to certain sucking insects' infestation. M.Sc. Thesis Fac. Agric., Cairo Univ., 1996, 190.

23. Riemer J, Whittaker JB. Air pollution and insect herbivores: Observed interactions and possible mechanisms. In: E.A. Bermays, Editor, Insect-Plant Interactions, CRC-Press, Boca Raton, Florida, 1989, 73-105.

24. Salem HA. Factors contributing to the distribution and level of attack of scale insects which infections some different varieties of mango fruit trees. M. Sc Thesis, Fac. Agric., Zagazig Univ., Egypt, 1994, 194.

25. Selim AA. Integrated control of Scale insects on certain fruit trees. Ph.D. Diss, Fac. Agric., Al-Azhar Univ., 2002, 173.

26. Semeada AM. Relative Susceptibility of certain maize germplasm to infestation with greater sugar- can borer, Sesamia critica Led. (Lepidoptera: Noctuidea) M.Sc. Thesis Fac. Agric., Cairo Univ., 1985, 240.

27. Soliman MMM, Kwaiz FAM, Shalby SEM. Efficiency of certain miscible oils and chlorpyriphos methyl insecticide against the soft scale insect, Kilifia acuminata Signoret (Homoptera: Coccidae) and their toxicities on rats. Archives of Phythetopathology and Plant Protection. 2007; 40(4):237-245. 